Proc. Estonian Acad. Sci. Geol., 2006, 55, 4, 259-268

\title{
A new type of shell structure in a phosphatic brachiopod from the Cambrian of Estonia
}

\author{
Jüri Nemliher \\ Institute of Geology at Tallinn University of Technology, Ehitajate tee 5, 19086 Tallinn, Estonia; \\ nemliher@gi.ee \\ Received 26 April 2006, in revised form 31 July 2006

\begin{abstract}
Shell structures of Ungula ingrica, U. inornata, and Ungula sp. 1 (Kallavere and Ülgase formations) from Cambrian sandstones of the Mäekalda section in Tallinn, Estonia, were studied. Specific alterations were recorded in the shell structures of $U$. ingrica and Ungula sp. 1. Several generations of precipitation of phosphatic matter inside the shells could be distinguished, marking (1) original biomineralization events, (2) phosphatization of soft tissues, and (3) later diagenetic alteration of mineral matter and/or structures inside the shells. The shells of $U$. inornata and $U$. ingrica were found to represent the baculate structure type typical of the genus. The shell structure of Ungula sp. 1 is different, consisting of alternating compact and primarily organic-rich laminae. No bacula were found in the latter laminae. Compact laminae are penetrated by tubuli, filled with phosphatized organic matter. This structure type is termed here as tubulate shell structure.
\end{abstract}

Key words: Lingulata, Ungula, shell structure, Cambrian, Estonia.

\section{INTRODUCTION}

Lingulates are known since the Early Cambrian and represent the oldest survived group of organisms characterized by phosphatic biomineralization. One of the diagnostic features of the class Lingulata is a native chitino-phosphatic shell (Gorjansky \& Popov 1986).

The shell structures of lingulates, both fossil and Recent, have been described for more than a century (Gratiolet 1860). However, detailed studies of shell structure as a diagnostic tool have mainly been carried out in the last three decades (Iwata 1981; Pan \& Watabe 1988; Holmer 1989; Ushatinskaya 1990; Williams \& Holmer 1992; Williams et al. 1994, 1998, 2004; Williams \& Cusack 1999; Skovsted \& Holmer 2003; Streng \& Holmer 2005). These studies have revealed several structure types of Cambrian-Ordovician lingulates: columnar (characteristic of acrotretids), baculate (obolids), and laminar (paterinids). Siphonotretid brachiopods have a specific shell structure, typically with prismatic laths and rods in the secondary layer 
(Williams et al. 2004). A unique shell structure of one of the oldest lingulates Mickwitzia - differs from all other types, showing, however, some features, close to that of acrotretids. These structure types can be used as a tool in taxonomic studies.

In the present research the shell structures of Ungula sp. 1 of Popov and Khazanovitch (in Popov et al. 1989), U. inornata (Mickwitz), and U. ingrica (Eichwald), originating from the Mäekalda section, Estonia, are studied and compared in order to clarify their affinity and preservation history.

\section{GEOLOGICAL SETTING}

The Upper Cambrian-Lower Ordovician succession of the northeastern part of the East European Platform is represented by siliciclastic sandy rocks with lenslike or cross-bedded structure and numerous gaps of different duration (Mens et al. 1990). The Upper Cambrian rock units of the Baltic palaeobasin are incomplete, both vertically and laterally (Heinsalu \& Viira 1997; Mens \& Pirrus 1997). Layers rich in intact shells and shell fragments of lingulate brachiopods, forming phosphorite deposits of commercial interest, occur at certain levels of this succession (Raudsep 1987). In Estonia the main accumulations of such lingulate coquinas are attributed to the Ülgase (U. inornata Biozone), Tsitre (Schmidtites celatus Biozone), and Kallavere (U. ingrica Biozone) formations. In the Mäekalda section only the Ülgase and Kallavere formations crop out (see also fig. 5 in Mens et al. 1999). Preservation of shells is quite variable, especially in the Kallavere Formation where the basal coquina consists mostly of repeatedly redeposited shell fragments. In the other specified formations the lingulate shells are typically better preserved.

Starting from the first palaeontological description of Obolus apollinis (Eichwald 1829), the systematic position of lingulates from the above-mentioned formations has been a topic of discussion for about two centuries. The present knowledge on the palaeontology of lingulates from these beds is summarized in Popov et al. (1989) and Puura (1996).

L. E. Popov and K. K. Khazanovitch (in Popov et al. 1989) described a new specimen from the basal conglomerate of the Ülgase Formation at Ülgase Village near Tallinn. As the shells were poorly preserved, but differed from the lingulate species formerly known in the region, they were referred to as Ungula sp. 1. Mens et al. (1999) documented phosphatic shells from the basal conglomerate of the Ülgase Formation in the Mäekalda section and assigned them tentatively to Ungula sp. 1 sensu Popov and Khazanovitch. However, due to poor preservation of shells, the precise systematic position of this species is not known. The material studied in this paper is tentatively referred to as Ungula sp. 1. Although the systematic position of that brachiopod is uncertain, its shell structure is of interest as it differs from those of the other Cambrian lingulate brachiopods identified in the same region. Presumably the pebbles that yielded the specimens originate from the eroded part of the earliest Upper Cambrian (Mens et al. 1999). 


\section{MATERIAL AND METHODS}

The Mäekalda section, which is no longer accessible, was exposed along a road cut in the city of Tallinn (see Mens et al. 1989, 1999 for location and stratigraphical details). The section was sampled during fieldwork in 1987 as follows: pebbles from the basal conglomerate of the Ülgase Formation (N-62), lingulate brachiopod shells from the Ülgase Formation (N-63 and N-63A), and basal lingulate shell coquina of the Kallavere Formation (N-60). All samples are deposited in the Department of Collections of the Institute of Geology at Tallinn University of Technology.

Valves of Ungula sp. 1 (sensu Popov and Khazanovitch) were extracted mechanically from pebbles of the basal conglomerate of the Ülgase Formation. Besides, a number of pebbles were cut with a diamond saw in order to reveal the cross-sections of shells. Valves of U. inornata (Mickwitz) from the Ülgase Formation and $U$. ingrica (Eichwald) from the Kallavere Formation were picked out of weakly cemented sandstone.

Fractured and polished cross-sections of shells, untreated and treated with $10 \% \mathrm{HCl}(30 \mathrm{~s})$ or $20 \% \mathrm{H}_{2} \mathrm{O}_{2}$ (about $3 \mathrm{~min}$ ), were studied. After treatment shells were washed with distilled water, dried, mounted, covered with gold, and examined under SEM, Tesla BS 300 equipment, operating at $20 \mathrm{KeV}$. Altogether, 51 crosssections were examined.

\section{RESULTS AND DISCUSSION}

Representatives of the genus Ungula have a baculate shell structure. Holmer (1989) established this structure type on specimens of $U$. ingrica from the basal beds of the Kallavere Formation in the Jägala-Joa section, Estonia.

Shell architecture of the studied samples of U. ingrica and U. inornata was identified as belonging to the baculate type. This structure is typically an alternation of compact (primarily, layers with a higher mineral content) and baculate laminae. The latter are primarily organic-rich layers in the shell, containing a large number of originally mineralized particles forming the bacula. This shell architecture should be considered as the primary shell structure type of the genus Ungula.

Ungula ingrica. The typical shell structure of this species shows an alternation of thin compact (c) (commonly ranging from a few micrometres to $10 \mu \mathrm{m}$ ) and much thicker baculate (b) $(20-30 \mu \mathrm{m})$ laminae (Pl. I, fig. 1). However, the structure of the specimens from the Mäekalda section is variously preserved, presumably due to the influence of taphonomic processes on the accumulation of shells and diagenetic alteration of different extent and intensity. So, valves showing an almost homogeneous appearance of the shell in cross-section are abundant. Etching, however, brings forth alternation of compact (c) and baculate (b) laminae (P1. I, fig. 2), while compact laminae have a multi-lamellae (sensu Holmer 1989) structure. It is assumed that homogenization of baculate laminae has taken place due to a large amount of secondarily added apatitic material, formed via phosphati- 
PLATE I

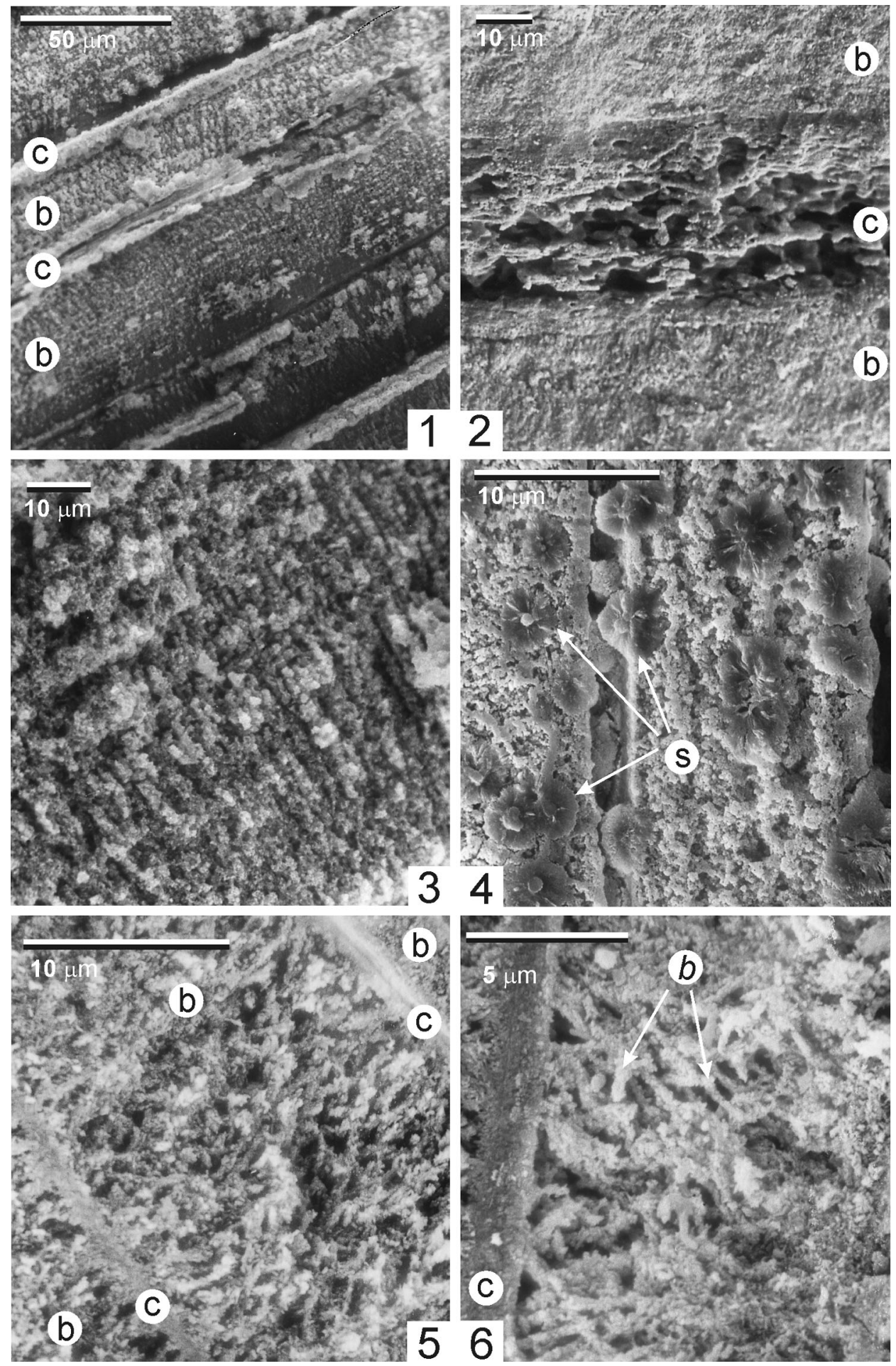


zation of the organic compound in baculate laminae. This second generation of apatitic matter inside shells has a characteristic structure and has been termed as collophanous calcium phosphate (CCP) by Holmer (1989).

Phosphatization of organic matter requires an alkaline and reducing (micro-) environment (Briggs \& Kear 1993). Such conditions in the earliest stages of post mortem development of lingulate valves are confirmed by the typical dark colour and high pyrite content (detected by the X-ray diffraction method) of $U$. ingrica shells from the Mäekalda section (Nemliher \& Puura 1996a). Nemliher et al. (2004) have identified the presence of both, primarily secreted and secondarily added apatite varieties in shells of lingulate brachiopods from the Obolus-sandstone of the Northeastern European Platform. This serves as another evidence of the conditions conducing to organic matter phosphatization in shells at the very early diagenetic stages.

A common structure observed in shells of $U$. ingrica is chains of spherical phosphatic particles inside baculate laminae, arranged perpendicular to the compact lamina (Pl. I, fig. 3). This structure, similar to the structural unit "walled lamina" in terms of Williams et al. (1994), is also interpreted here as being formed post mortem as a result of phosphatization of the original structure of the organic matter in the shell.

The above-described variations in shell architecture of U. ingrica have been complicated by later diagenetic alteration. Among them the third generation of apatite can be clearly distinguished (P1. I, fig. 4), building well-distinguishable

\section{Explanation of Plate I}

Fig. 1. Fractured cross-section of a dorsal valve of Ungula ingrica, etched with $10 \% \mathrm{HCl}$, sample N-60-27, basal coquina of the Kallavere Formation. Alternation of compact (c) and baculate (b) laminae.

Fig. 2. Fractured cross-section of a dorsal valve of Ungula ingrica, etched with $10 \% \mathrm{HCl}$, sample N-60-3, basal coquina of the Kallavere Formation. Structure of a poorly preserved but obviously multilayered primarily compact (c) lamina between possibly primary baculate laminae (b).

Fig. 3. Fractured cross-section of the dorsal valve of Ungula ingrica, etched with $10 \% \mathrm{HCl}$, sample N-60-27, basal coquina of the Kallavere Formation. Altered structure of a baculate lamina, displaying the arrangement of apatitic particles, formed during phosphatization of organic matter inside the shell, perpendicular to the compact lamina.

Fig. 4. Polished and etched $(10 \% \mathrm{HCl})$ cross-section of a dorsal valve of Ungula ingrica, sample N-60-60, basal coquina of the Kallavere Formation. Spherulitic apatite bodies (s) of the third generation of apatite, displaying typical radial structure.

Fig. 5. Fractured cross-section of a dorsal valve of Ungula inornata, treated with $20 \% \mathrm{H}_{2} \mathrm{O}_{2}$, sample N-63A-17, Ülgase Formation. Typical baculate structure, showing alternation of baculate (b) and compact laminae (c).

Fig. 6. Fractured cross-section of a dorsal valve of Ungula inornata, treated with $20 \% \mathrm{H}_{2} \mathrm{O}_{2}$, sample N-64A-15, Ülgase Formation. Structure of a baculate lamina, displaying the characteristic shape of the bacula $(b)$. Note the small amount of secondary apatite filling the space between the bacula. 
spherical bodies (s) inside the shell. Typically, the dimensions of these spherulites are about $2-3 \mu \mathrm{m}$. They have a radial structure and have been reported to be common in secondarily altered biological phosphates (Nemliher 2001) as well as in phosphates of diagenetic origin (Nemliher \& Puura 1996b).

Ungula inornata. Compared to $U$. ingrica, the shell structure of $U$. inornata from the studied section of the Ülgase Formation is much less variable. Only the baculate shell structure type has been identified (Pl. I, fig. 5), resembling that of $U$. ingrica structure in compact laminae as well as in the nature and orientation of bacula (b in Pl. I, fig. 6). Possibly, due to preservation of only primarily mineralized shell components (the first apatite generation), the shell structure is the same as in Tilasia rugosa (Holmer 1991) or Obolus apollinis (Williams \& Cusack 1999). This interpretation is supported by the light colour of U. inornata shells from the Ülgase Formation of the Mäekalda section as well as by the absence of pyrite in the shells, indicating lack of strong reducing environmental conditions.

Ungula sp. 1. As in all lingulates, shells of this species are built up of a rhythmic alternation of laminae marking different mineralized tissue secretion events (Pl. II, fig. 1). They are called here "organic layers" (o in Pl. II, fig. 1) due to the lack of bacula in primarily organic-rich layers. However, the fine microstructure of these organic layers is very similar to that of the baculate layer in U. ingrica (cf. Pl. I, fig. 1 and Pl. II, fig. 1), which refers to the CCP nature of the former. Thus, it is assumed here that those layers were initially organic-rich (= baculate layer of $U$. ingrica), filled with the apatite formed due to phosphatization of organic matter inside the valve.

\section{Explanation of Plate II}

Fig. 1. Polished cross-section of a phosphatized pebble containing a valve of Ungula sp. 1 (?), etched with $10 \% \mathrm{HCl}$, sample N-62-54, basal conglomerate of the Ülgase Formation. Alternation of compact (c) and primarily organic-rich laminae (o). Q, quartz grain, p, phosphatic cement of the pebble. Note the similarity between the structures of organic layers and phosphatic cement.

Fig. 2. Polished cross-section of a dorsal valve of Ungula sp. 1, etched with $10 \% \mathrm{HCl}$, sample $\mathrm{N}-62-52$, basal conglomerate of the Ülgase Formation. Alternation of compact (c) and primarily organic-rich laminae (o). Compact laminae, displaying a multi-lamellae structure, are penetrated by tubuli $(\mathrm{T})$.

Fig. 3. Polished cross-section of a dorsal valve of Ungula sp. 1, etched with $10 \% \mathrm{HCl}$, sample N-62-52, basal conglomerate of the Ülgase Formation. Compact lamina (c), displaying a multilamellae structure, is penetrated by a tubulus $(\mathrm{T})$.

Fig. 4. Polished cross-section of a dorsal valve of Ungula sp. 1, etched with $10 \% \mathrm{HCl}$, sample N-62-52, basal conglomerate of the Ülgase Formation. Tubulus (T) in the compact (c) lamina. Note the similarity between the structures of apatite filling the organic layer (o) and tubulus.

Fig. 5. Polished cross-section of a dorsal valve of Ungula sp. 1, treated with $20 \% \mathrm{H}_{2} \mathrm{O}_{2}$ sample N-62-4, basal conglomerate of the Ülgase Formation. The organic layers (o) display a homogeneous structure, while the compact (c) lamina reveals multi-lamellae architecture.

Fig. 6. Polished cross-section of a dorsal valve of Ungula sp. 1, etched with $10 \% \mathrm{HCl}$, sample N-62-11, basal conglomerate of the Ülgase Formation. The compact lamina is formed of lamellae (I). 
PLATE II
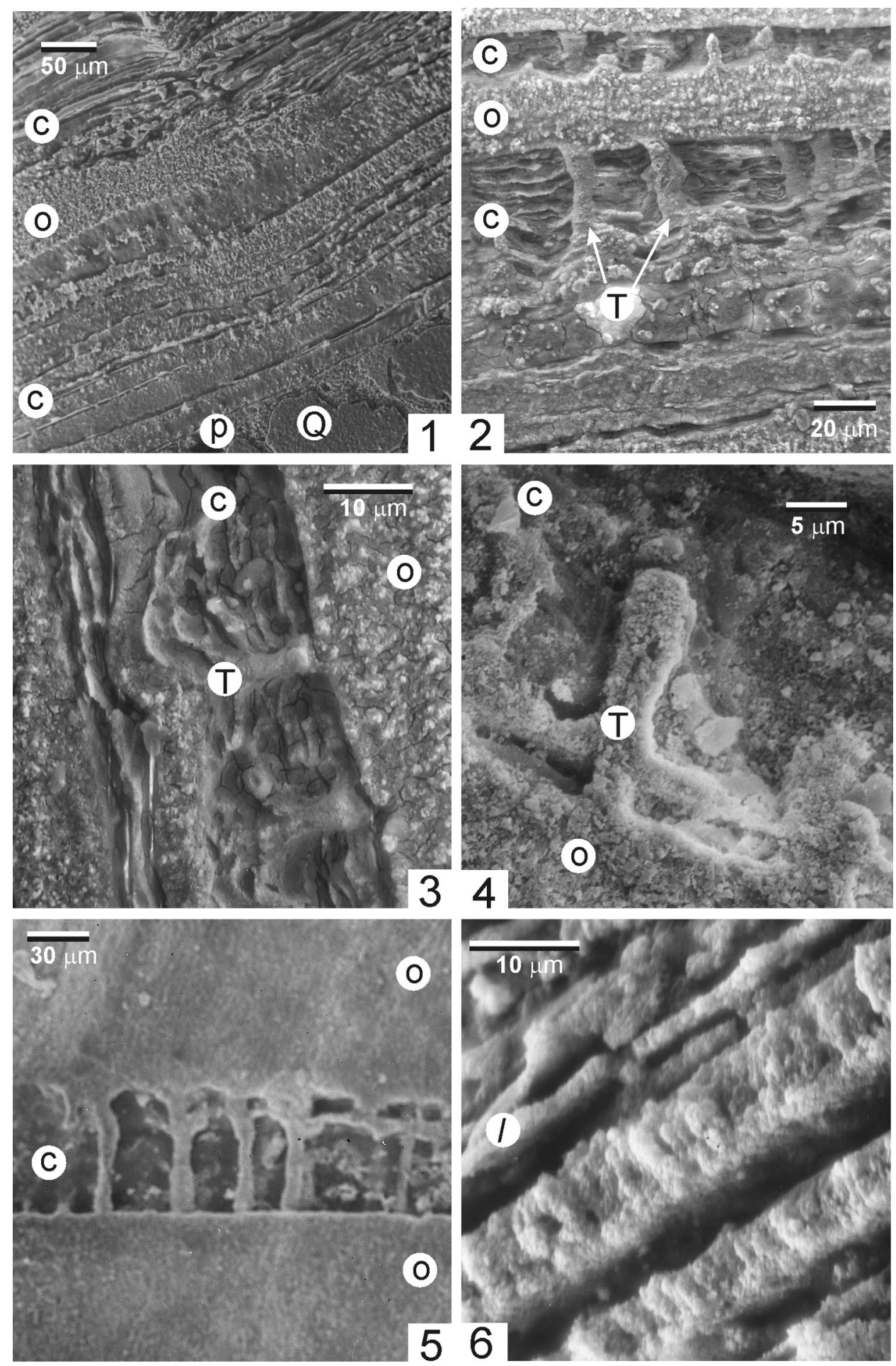
Generally the shell structure of Ungula sp. 1 consists of an alternation of compact and organic layers. A distinctive feature of this taxon is that compact laminae may be penetrated by tube-like structures, typically about $4 \mu \mathrm{m}$ in diameter (termed here as tubuli; $\mathrm{T}$ in Pl. II, figs 2, 3), beginning from organic layers and often not reaching the next compact lamina (Pl. II, fig. 4). No bacula were detected in the "baculate" lamina (organic layer or chitine layer sensu Iwata 1981). On the contrary, the structure of the compact lamina resembles that of the baculate structure type (Pl. II, figs 2, 3,6). Proceeding from that it might be concluded that tubuli, filled with organic matter and emanating from organic layers, penetrate the primarily mineralized (= compact) laminae (Pl. II, fig. 4). Such organization of shell architecture of fossil obolids is called here a tubulate shell structure.

It is important to note that the described feature of the shell structure of Ungula sp. 1 is different from the columnar structure of acrotretoid brachiopod shells (Williams \& Holmer 1992), as well as from that of Mickwitzia shells (Skovsted \& Holmer 2003), where columns penetrate initially organic-rich layers.

The shell structure of Ungula sp. 1, like that of U. ingrica, occurring in the basal beds of the Kallavere Formation, is variably preserved. However, more or less homogeneous shells without baculate architecture can be found (Pl. II, fig. 5). Similarly to $U$. ingrica, the multi-lamellae $(I)$ structure of the compact lamina has been revealed after etching (Pl. II, fig. 6).

It may be concluded that the tubulate shell architecture of Ungula sp. 1 should be regarded as primary and biologically formed one. So, in spite of the similarity in the shell morphology of Ungula sp. 1, U. ingrica, and U. inornata, the taxonomic position of Ungula sp. 1 in the genus Ungula is tentative.

\section{CONCLUSIONS}

Several generations of phosphatic matter precipitation were recorded in the shells of fossil lingulates from the Cambrian part of the Mäekalda section, marking

(1) original biomineralization events, (2) phosphatization of organic matter, and

(3) later diagenetic alteration of mineral matter/structures inside fossil shells. The following conclusions can be drawn:

1. Shells of U. ingrica from the Kallavere Formation have a typical baculate structure. Large-scale variation in the preservation of shell structure and the extent of secondary changes indicate different post mortem, transportation, and postsedimentary conditions during the Kallavere Age.

2. Shells of $U$. inornata from the Ülgase Formation have also a baculate structure. Variations and the extent of secondary changes in the shell structure of this species are less substantial, indicating constant post mortem, transportation, and postsedimentary conditions during the Ülgase Age.

3. Shells of Ungula sp. 1 from the basal conglomerate pebbles of the Ülgase Formation have a tubulate structure. For this reason this species cannot probably be assigned to the genus Ungula. Large-scale variations in the preservation of 
the shell structure with numerous secondary alterations indicate heterogeneity of post mortem, transportation, and postsedimentary conditions during the preÜlgase Age.

\section{ACKNOWLEDGEMENTS}

I would like to thank Dr. Ursula Toom for assistance with the SEM and Prof. Dimitri Kaljo for fruitful discussions and suggestions. Valuable comments and suggestions of the reviewers are much appreciated. This work was supported by grant No. 5922 of the Estonian Science Foundation.

\section{REFERENCES}

Briggs, D. E. G. \& Kear, A. J. 1993. Fossilization of soft tissue in the laboratory. Science, 259, 1439-1442.

Eichwald, E. 1829. Zoologia speciale, quam exposits animalibus tum vivis, tum fossilibus potissium Rossae in universum et Poloniae in specie, etc. Ps 1. Propae deuticam zoologiae atque specialem Heterozoorum expositionem continens. Vilnae.

Gorjansky, V. Yu. \& Popov, L. E. 1986. On the origin and systematic position of the calcareousshelled inarticulate brachiopods. Lethaia, 19, 233-240.

Gratiolet, L. P. 1860. Recherches pour servir à l'historie des Brachiopodes. Ètudes anatomiques sur la Lingule anatine (L. anatina Lam). J. Conchyol., 4, 49-172.

Heinsalu, H. \& Viira, V. 1997. Pakerort Stage. In Geology and Mineral Resources of Estonia (Raukas, A. \& Teedumäe, A., eds), pp. 52-58. Estonian Academy Publishers, Tallinn.

Holmer, L. E. 1989. Middle Ordovician phosphatic inarticulate brachiopods from Västergötland and Dalarna, Sweden. Fossils Strata, 26, 1-172.

Holmer, L. E. 1991. The taxonomy and shell characteristics of a new elkaniid brachiopod from the Ashgill of Sweden. Palaeontology, 34, 195-204.

Iwata, K. 1981. Ultrastructure and mineralization of the shell of Lingula unguis Linne (inarticulate brachiopod). J. Fac. Sci. Hokkaido Univ., 20, 35-65.

Mens, K. \& Pirrus, E. 1997. Sedimentary cover. Cambrian. In Geology and Mineral Resources of Estonia (Raukas, A. \& Teedumäe, A., eds), pp. 39-51. Estonian Academy Publishers, Tallinn.

Mens, K., Viira, V., Paalits, I. \& Puura, I. 1989. Cambrian-Ordovician boundary beds at Mäekalda, Tallinn, North Estonia. Proc. Estonian Acad. Sci. Geol., 38, 101-111.

Mens, K., Bergström, J. \& Lendzion, K. 1990. The Cambrian System on the East European Platform. Correlation chart and explanatory notes. IUGS Publ., 25.

Mens, K., Paalits, I. \& Puura, I. 1999. Biostratigraphic dating of pebbles from the Upper Cambrian conglomerates in Estonia. Proc. Estonian Acad. Sci. Geol., 48, 140-157.

Nemliher, J. 2001. The shell structure and mineralogy of Mickwitzia (Lingulata: Brachiopoda) from the Lower Cambrian Kakumäe Beds of Estonia. Proc. Estonian Acad. Sci. Geol., 50, 43-50.

Nemliher, J. \& Puura, I. 1996a. Shell mineralogy of the lingulate brachiopods from the Baltic "Obolus phosphorite". Geol. Surv. Denmark and Greenland. Report Ser., 98, 83-91.

Nemliher, J. \& Puura, I. 1996b. Upper Cambrian basal conglomerate of the Kallavere Formation on the Pakri Peninsula, NW Estonia. Proc. Estonian Acad. Sci. Geol., 45, 1-8.

Nemliher, J., Kurvits, T., Kallaste, T. \& Puura, I. 2004. Apatite varieties in the shell of the Cambrian lingulate brachiopod Obolus apollinis Eichwald. Proc. Estonian Acad. Sci. Geol., 53, 246 256. 
Pan, C.-M. \& Watabe, N. 1988. Shell growth of Glottidia pyramidata Stimpson (Brachiopoda: Inarticulata). J. Exp. Biol. Ecol., 119, 43-53.

Popov, L. E., Khazanovitch, K. K., Borovko, N. G., Sergeyeva, S. P. \& Sobolevskaya, R. F. 1989. The key sections and stratigraphy of the phosphate-bearing Obolus-beds on the North-East of Russian Platform. AN SSSR, Mezhvedomstvennyj stratigraf. komitet SSSR, Trudy, 18. Nauka, Leningrad (in Russian).

Puura, I. 1996. Lingulate Brachiopods and Biostratigraphy of the Cambrian-Ordovician Boundary Beds in Baltoscandia. Doctoral thesis, Department of Historical Geology \& Palaeontology, Institute of Earth Sciences, Uppsala University.

Raudsep, R. 1987. Shelly (Obolus) phosphorite. In Geology and Mineral Resources of the Rakvere Phosphorite-Bearing Area (Puura, V., ed.), pp. 128-142, 147-151. Valgus, Tallinn.

Skovsted, C. B. \& Holmer, L. E. 2003. The Early Cambrian (Botomian) stem group brachiopod Mickwitzia from Northeast Greenland. Acta Palaeont. Pol., 48, 1-20.

Streng, M. \& Holmer, L. E. 2005. Discovery of a new type of shell structure within the organophosphatic brachiopods and the status of the family Curticiidae. $G F F, 127,7-16$.

Ushatinskaya, G. T. 1990. Microstructure and shell secretion in inarticulate brachiopods of the Order Acrotretida. Paleont. Zhurn., 3, 55-65 (in Russian).

Williams, A. \& Cusack, M. 1999. Evolution of a rhythmic lamination in the organophosphatic shells of brachiopods. J. Struct. Biol., 126, 227-240.

Williams, A. \& Holmer, L. E. 1992. Ornamentation and shell structure of acrotretoid brachiopods. Palaeontology, 35, 657-692.

Williams, A., Cusack, M. \& Mackay, S. 1994. Collagenous chitinophosphatic shell of the brachiopod Lingula. Phil. Trans. Roy. Soc. London, B, 346, 223-266.

Williams, A., Cusack, M. \& Buckman, J. O. 1998. Chemico-structural phylogeny of the discinoid brachiopod shell. Phil. Trans. Roy. Soc. London, B, 353, 2005-2038.

Williams, A., Holmer, L. E. \& Cusack, M. 2004. Chemico-structure of the organophosphatic shells of siphonotretide brachiopods. Palaeontology, 47, 1313-1337.

\section{Eesti Kambriumist pärinevate fosfaatse kojaga käsijalgsete poolmete uus struktuuritüüp}

\section{Jüri Nemliher}

On uuritud Tallinnas asunud Mäekalda paljandi Kambriumi liivakividest pärinevate Ungula ingrica, Ungula inornata ja Ungula sp. 1 (Kallavere ja Ülgase kihistud) karbistruktuure. Liikide Ungula ingrica ja Ungula sp. 1 poolmetes on tuvastatud spetsiifiliste muutuste olemasolu - võimalik on eristada mitmeid apatiitse ainese generatsioone, mis märgivad: (1) biomineralisatsioonil tekkinud originaalset poolmete struktuuri; (2) poolmetes sisaldunud orgaanilise aine fosfatiseerumist; (3) hilisemat, diageneesi etapil aset leidnud mineraalse ainese poolmesisest ümberjaotumist. On leitud, et Ungula ingrica ja Ungula inornata poolmed on tüüpiliselt bakulaatse struktuuriga, mis on sellele perekonnale omane. Ungula sp. 1 poolmete struktuur seevastu on üles ehitatud mineraliseerunud ja algselt orgaanikarikaste kihtide vaheldumisena; viimastes pole baakulaid leitud. Mineraalsed kihid on läbistatud torujate struktuuride poolt (tubuli), mis on täidetud fosfatiseerunud orgaanilise ainega. Selline struktuuritüüp on nimetatud tubulaatseks poolmete struktuuriks. 